\title{
XV. YÜZYILDA AKHİSAR'I İHYA EDEN BİR HAYIRSEVER: SARI AHMED PAŞA VE VAKFI ${ }^{1}$
}

\author{
Dr. Ömer BIYIK \\ Ege Üniversitesi, Edebiyat Fakültesi, \\ Tarih Bölümü
}

\begin{abstract}
ÖZ
Sarı Ahmed Paşa, XV. yüzyılda yaşamış, hayırseverliği ile tanınan bir Osmanlı devlet adamıdır. Akhisar'da içerisinde cami, mektep, medrese, imaret, hamam ve hanın yer aldığı bir külliye inşa ettirmiş ve bu yapıların yaşatılması gayesi ile bir vakıf tesis etmiştir. Kurduğu vakıf ve yaptırdı ̆̆ sağlamıştır. 530 yıllık bir geçmişe sahip ve oldukça zengin olduğu anlaşılan Sarı Ahmed Paşa Imaret Vakfi, günümüze kadar intikal etmiştir. Vakıf hâlâ topluma hizmet etme noktasında işlevini sürdürmektedir. Çalışmamız, Ahmed Paşa'nın hayatı ve eserlerine ait orijinal bilgiler sunmakla birlikte, Akhisar başta olmak üzere, Manisa, Göl Marmara, Bergama, Edremit, Kemer ve Ayazmend merkezlerinin kültürel tarihine katkı sağlayacaktır.
\end{abstract}

Anahtar Kelimeler: Sarı Ahmed Paşa, Külliye, Osmanlı Devleti, Vakıf, Imaret, Akhisar, Manisa.

\section{A PHILANTHROPIST WHO REVIVED AKHISAR IN THE $15^{\text {TH }}$ CENTURY: SARI AHMED PASHA AND HIS FOUNDATION}

\begin{abstract}
Sarl Ahmed Pasha, who lived in $15^{\text {th }}$ century, was an Ottoman statesman known by his philanthropy. He built a complex of buildings in which a mosque, a school, a madrasah, an imaret, a hammam and a caravanserai were located and he established a foundation for the purpose of maintain these buildings in a good condition. The established foundation and the buildings had a great role in the development of Akhisar. With its 530 years of history, the heritage of the Sart Ahmed Pasha foundation is still with us today and it is quite rich. The foundation still continues its function of serving community. This study will provide contributions to enlighten the cultural history of the centers of, mainly, Akhisar, and of Manisa, Göl Marmara, Bergama, Edremit, Kemer, and Ayazmend as well as serving original information about Ahmed Pasha's biography and his works.
\end{abstract}

Keywords: Sarl Ahmed Pasha, Külliye, Ottoman State, Waqf, Imaret, Akhisar, Manisa.

\footnotetext{
${ }^{1}$ Makalenin geliş tarihi: 25.12 .2014

Makalenin kabul tarihi: 03.03.2015
} 


\section{GIRIŞ}

Saruhanoğulları Beyliği'nin Osmanlı Devleti'nin egemenliğine girmesiyle, XV. yüzyıldan itibaren Manisa Sancağı'na bağlı bir kaza olarak idare edilen Akhisar, Türk-İslam şehri kimliğinde, birçok büyük şahsiyetin kurduğu vakıflar sayesinde gelişme göstermiştir. Bunlar arasında, XV. yüzyılda yaşamış, Osmanlı Devleti'nde devlet adamı olarak da hizmet etmiş olan Sarı Ahmed Paşa, toplumun ihtiyaç duyduğu sosyal ve dini yapıları inşa ederek Akhisar'ı ihya etmiştir. Servetini hayır işlerine harcayan Paşa, kurduğu vakıf ile elde ettiklerini insanlığın hizmetine sunmuştur. Tesis ettiği vakıf sayesinde yaptırdığı eserler günümüze kadar ulaşmış, hâlâ hizmet noktasında faal olarak işlevini sürdürmektedir.

Çalışmamızda faaliyetleriyle Akhisar'ın bânisi olan Sarı Ahmed Paşa'yı ve kurduğu vakfi, Tapu ve Kadastro Genel Müdürlüğü Arşivi'nden temin ettiğimiz vakfiyeler 1şı̆̆ında inceledik. Bunun yanında 1577 yılına ait Saruhan Sancağl Evkaf Defteri'nde yer alan Ahmed Paşa' ya verilen mülknâme sureti ve vakfiyla ilgili bilgilerden de istifade ettik. Ayrıca Başbakanlık Osmanlı Arşivi'nde bulunan vakfa ait arşiv vesikalarını da değerlendirdik.

$\mathrm{Bu}$ çalışma, Ahmed Paşa'nın kimliği ile ilgili bir takım sorulara cevap vermektedir. Ayrıca kurduğu vakfın mâli büyüklüğü hakkında orijinal bilgiler de sunmaktadır. Vakfin geçmişteki durumu ile günümüz halinin karşılaştırılmasına imkan sağlamaktadır. Diğer yandan Türk-İslam dünyasında insanlığa hizmet etmiş büyük şahsiyetleri tanıtmayı ve köklü bir geçmişe sahip olan Akhisar'ın tarihsel gelişimine katkı sağlamayı hedeflemektedir.

\section{Sarı Ahmed Paşa'nın Hayatı}

Osmanlı Devleti'nde Fatih Mehmed (1451-1481) ve II. Bayezid (14811512) dönemlerinde görev yapan Ahmed Paşa'nın devşirme kökenli bir devlet adamı olduğu anlaşılmaktadır. Kendisine ait 1 Rebiülevvel 889 (29 Mart 1484) ve Evâhir-i Receb 893 (Haziran 1488) tarihli iki vakfiyede ismi Ahmed Paşa bin Abdüssâmed olarak geçmektedir ${ }^{2}$. Akhisar'da kendi adıyla anılan caminin haziresinde yer alan mezar taşında ise Ahmed Paşa bin Abdullah yazılıdır ${ }^{3}$. Osmanlı Devleti'nin ilk dönemlerinde kul kökenli yöneticilere ait vakfiyelerinin başında padişah tuğrası yer alırdı (Yüksel, 2012, s.468). Ahmed Paşa'nın vakfiyesinin başında da Sultan II. Bâyezid'e ait bir tuğra vardır.

\footnotetext{
${ }^{2}$ Ahmed Paşa'ya ait H. 1 Rebiülevvel 889 (29 Mart 1484) tarihli vakfiye Tapu Kadastro Genel Müdürlüğü, Tapu Arşiv Dairesi Başkanlığı, Vakf-1 Cedid Defterleri Fonu'nda 205 numarada kayıtlıdır. (Bu vakfiye bundan sonra Vakfiye I olarak anılacaktır). Aynı yerde bu vakfiyeden hemen sonra H. Evâhir-i Receb 893 (Haziran 1488) tarihli ikinci bir vakfiye daha vardır. Bunun ilk vakfiyenin zeyli olduğu anlaşılmaktadır. (Bu vakfiye bundan sonra Vakfiye II olarak anılacaktır)

3 Osmanlı döneminde devşirmeler, din değiştirip Müslüman olanlar baba adı olarak "Allahın kulu " anlamına gelen Abdullah, Abdüssamed, Abdülmennan gibi isimleri alırlard1.
} 
Osmanlı kroniklerinde ve döneme ait kayıtlarda kimliği ile ilgili yeterli bilgi $^{4}$ bulunmasa da onun üst düzey yöneticilik görevini hâiz bir devlet adamı olduğu konusunda ciddi işaretlerden bahsetmek mümkündür. Nitekim, Vakfiye I'de kendisinden "el-emîrü'l-kebîr, müdebbir-i umûri'd-devleti'l-kâhire, muhyii merâsimi's-saltanati'l-fâhire, kıdvet-i erbâbi'l-ikbâl, isvet-i ashâbi'l- iclâl, zâbit-i eâzımi'l-umûr, nâzım-1 mesâlihi'l-cumhûr, sâhibü'l-hayrât ve'l-hasenât yenbu'ü'l-kurb ve't-ta'ât, el-mahsûs bi-mezîd-i avâtıf-1 meliki'l-arz ve'ssemavât Ahmed Paşa bin Abdüssamed" olarak söz edilmiştir. Osmanlı Devleti'nde yöneticiler için kullanılan elkablar incelendiğinde, Ahmed Paşa için belirtilen sıfatların, vezir ya da beylerbeyi gibi üst düzey yöneticilere mahsus olduğu anlaşılmaktadır ${ }^{5}$. Diğer yandan Vakfiye II'de ise "el-vâkıfü'l-mübîr, elemîrü'l-kebîr, sâhibü'l-hayrât ve'l-hasenât, yenbu'ü'l-kurb ve't-ta'ât, elmuhsinü'l-müebbed, Ahmed Paşa bin Abdüssamed" olarak belirtilmiştir'́.

Paşanın her iki vakfiyesinde yer alan şahitlerin kimliği, onun devlet merkezinde görev yapan önemli bir şahsiyet olduğunu kanitlar niteliktedir. Bunlar arasında Vezir Davud bin Abdülvedûd, Vezir Ahmed bin Yusuf, Kadıasker Ali bin Yusuf el-Fenarî ve Kadıasker Mehmed bin Beglik gibi dönemin önemli devlet adamları bulunuyordu? ${ }^{7}$ Y Yine devletin üst düzey memurluklarında görev yapan Ser Silahdar, Ser Çavuşân, Hazine-i Âmire Kâtibi, Divân Kâtibi gibi görevliler ile birlikte II. Bayezid devrinin meşhur âlimleri de yer allyordu 8 .

${ }^{4}$ Gerek Fatih Mehmed gerekse II. Bayezid dönemleri ile ilgili Osmanlı kroniklerinde Sarı Ahmed Paşa'nın kimliğini tanımlayan ya da onunla aynı şahıs olabileceğini düşündüren bir isimden söz edilmemektedir. Bununla ilgili olarak incelediğimiz Tursun Bey, Tarih-i Ebu'l-Feth, Haz. Mertol Tulum, İstanbul 1977; Kritovulus, Tarih-i Sultan Mehmed Han-l Sâni, (Trc. Karolidi), İstanbul 1328; Gelibolulu Mustafa Âli'nin Künhü'l-Ahbar, Fatih Sultan Mehmed Devri 1451-1481, C. II, (Haz. M. Hüdai Şentürk), TTK, Ankara 2003; Anonim Osmanl Kroniği (1299-1512), (Haz. Necdet Öztürk,) İstanbul 2000; Hoca Saadeddin Efendi, Tacü't-Tevarih, 3, (Haz. İsmet Parmaksızoğlu,), İstanbul 1979; Osmanzâde Ta'ib Ahmed, Hadikatü'l-Vüzera, Freiburg 1969, gibi eserlerde onun ismine dâir bir malumât elde edemedik. Ayrica Mehmed Süreyya'nın Sicill-i Osmanı̂' sinde de bu isme rastlanmaz.

${ }^{5} \mathrm{Bu}$ elkâb, "şan ve itibar sahibi büyük emîr, satvetli bir hükûmetin işlerini çekip çeviren, mefharetli bir saltanatın merâsimini ihya eden, erbâb-1 ikbalin önderi, büyük ve önemli işlerin nizamını muhafaza eden ve cumhurun işlerini düzenleyen, hayır ve hasenât sahibi" şeklinde sadeleştirilebilmektedir.

${ }^{6} \mathrm{Bu}$ elkab "Büyük emir, hayır hasenat sahibi " şeklinde sadeleştirilebilmektedir.

${ }^{7}$ Ahmed Paşa'nın vakfiyesine şahitlik edenler arasında üç vezir ile iki kazasker başta olmak üzere birçok devlet adamı yer almaktadır. Bunlardan Ali bin Yusuf el-Fenarî, tam adı ile Ali bin Yusuf Bâli bin Şemseddin Muhammed Fenarî, Osmanlı Devleti'nin ilk şeyhülislamı olan Molla Şemseddin Fenarî'nin torunu ve Sultan II. Bâyezid devrinde Rumeli Kazaskeridir. Bkz. Vakfiye I ve Vakfiye II

8 Bunlar arasında Sultan Korkud'un hocası Mevlanâ Muslihiddin b. Durudhan ile ulemâdan birçok şahsiyet yer almaktadır. Bkz. Vakfiye II 
Vakfiyelerdeki bilgilere göre, kendisinin Bilal Çelebi, Mahmud Çelebi ve Hasan Çelebi isminde 3 oğlu ile Meryem, Fatma, Rabia, Safiye ve Hadice isimli 5 kızı vardır. Paşanın ailesiyle ilgili bilgiler veren yerel araştırmacı Mehmet Emin Müderrisoğlu'na göre ${ }^{9}$, ailenin erkek soyu devam etmemiştir. Öte yandan torunlarından Hatice Hanım'ın, Akhisarlı önde gelen bir aile olan Ali zâde Osman Ağa oğlu Mehmed Ağa ile evliliğinden doğan çocuklar ve bundan mütevellid sonraki kuşaklar, vakfın idaresinde görev yapmışlardır. Günümüzde bu aileden gelenler vakfın yöneticiliğini sürdürmektedirler (Müderrisoğlu, 1956, s.22).

Vakfin idaresinde tevliyet görevinin bir dönem ikiye ayrıldığ kayıtlarda yer alan nısf-ı tevliyet ifadesinden anlaşılmaktadır ${ }^{10}$. 1770 ve 1813 yıllarına ait vakfa mütevelli tayini ile ilgili kayıtlar bunu kanıtlar niteliktedir (BOA, C.EV., 23390). Öte yandan evladiyyet iddiasıyla hak talep edenler kimi zaman vakfın idaresinde sıkıntılar yaşanmasına neden olmuştur. Bunlardan biri 13 Rebiülevvel 1140 (29 Ekim 1727) tarihli davada (BOA, C.EV., 3065), bir diğeri de 20 Receb 1178 (13 Ocak 1765) tarihli şikâyet mektubunda ifade edilmiştir (BOA, C.EV., 2312).

Ahmed Paşa'nın hayır-hasenât faaliyetleri, çocukları ve torunları tarafından devam ettirilmiştir. Kızlarından Safiye Hatun babası gibi hayırseverliği ile tanınmıştır. XVI. yüzyıla ait bir vakıf kaydında Safiye Hatun, Gördük çayı üzerinde Baba Burnu denilen yerde, Oluklu Değirmen adıyla bilinen bir değirmenini, meşayih erbâbından Süleyman Dede'nin mezarının bulunduğu yerde ikamet eden dervişlere vakfetmiştir (Erdoğru - Bıyık, 2014, s.194). Yine paşanın ikinci kuşak torunlarından olan, ulemâ sınıfindan müderris Abdurrahman Efendi, H. Şevval 1059 (Ekim 1649) tarihinde kurduğu vakıfla, her yıl Ramazan ayında Akhisar'daki Ahmed Paşa İmareti'nde ekmek, pilav ve zerde pişirilerek fakirlere dağıtılmasını şart koşmuştur (TKGMA, VAYS.VC., nr.205).

Ahmed Paşa'nın kabri, Akhisar'da kendi yaptırdığı ve Paşa Cami olarak bilinen caminin kuzey kısmındaki hazirede yer almaktadır. Mezar taşı kitabesinde yazıldığına göre $\mathrm{H}$. Evâil-i Zilkade 893 (Ekim 1488) tarihinde vefat etmiştir. Burada paşanın kabri ile birlikte birçok mezar taşı da bulunmaktadır. Bunların paşanın soyundan gelip gelmediklerine dâir yeterli bilgi mevcut değildir.

\footnotetext{
${ }^{9}$ Müderrisoğlu Ali-zâde ailesinden bazı kimselere dayandırarak verdiği bilgiye göre, Sarı Ahmed Paşa'nın Fatih Mehmed'in veziri olan Saruca Paşa olabileceğinden bahsetmektedir. Ayrıca Saruca Paşa'nın çağdaşı diğer bir vezir olan Zağanos Paşa ile de irtibatlandırmaktadır. Bkz. Mehmet Emin Müderrisoğlu, Akhisarlı Türk Büyükleri ve Eserleri, İzmir 1956, s.22.

${ }^{10}$ BOA, C.EV., 23390'da, 1813 y1lına ait belgede "medine-i Akhisar-1 Saruhan'a tâbi Akhisar'da vâki merhum ve mağfur Sarı Ahmed Paşa Vakfı'nın yevmi beş akçe vazife ile ber vech-i meşrut nısf-1 tevliyete mutasarrıf olan evlad-1 vâkıfdan Ali fevt olub" ifadesi yer almaktadır.
} 
Günümüzde Akhisar'ın mahallelerden birisi de Ahmed Paşa'nın isminden gelen Paşa Mahallesi' dir. Esasen bu mahalle ile ilgili en eski bilgilere XVI. yüzyıl kayıtlarında rastlıyoruz. 1530 yılında Ahmed Paşa Mahallesi 59 hâne idi (BA, TD, nr. 166, 1995, s.356). Feridun Emecen, XVI. yüzy1lda Akhisar'ın en kalabalık mahallelerden birisi olarak bu mahalleden bahseder, ancak ayrıntılı bilgi vermez (Emecen, 1989, s.237). Osmanlı Devleti'nde köy ya da mahalle gibi yerleşim birimlerinde fakirlerin avarız akçelerinin karşılanması amacıyla vakıflar kurulmuştu. Bu türden vakıflar, kurulduğu mahallenin ismiyle anılmaktayd1. XVI. yüzyılda Ahmed Paşa Mahallesi için de, "Evkâf-ı Avârız-ı Fukarâ-i Ahmed Paşa" isimli bir vakıf tesis edilmişti. Bu vakfa, varlıklı kimseler nakit para ya da geliri olan mülkleri bağışlamışlardır. Bu yolla fakirlerin avarız akçeleri devlete ödenmiştir. Bununla birlikte XVI. yüzyıl kayıtlarında Akhisar'da yine Ahmed Paşa ismiyle anılan bir çarşıdan da bahsedilmektedir (Erdoğru - B1yık, 2014, s.153).

Paşanın Akhisar'dan başka Manisa'ya bağlı Marmara Kazası'nda, Edremid Kazası'na bağlı Kemer Köyü'nde, Karesi Sancağı'na bağlı Ayazmend'de de yaptırdığı eserler bulunmaktaydı. 1530 yılında Kemer Köyü'ndeki hamam senelik 3.000 akçe gelire sahipti ${ }^{11}$. Ayazmend Kasabası'nda yine paşanın ismiyle anılan bir mahalle bulunuyordu. 1530 yılına ait bilgilerden Ahmed Paşa Mahallesi 'nin 38 hâne olduğu anlaşılmaktadır (BA, TD, nr. 166, 1995, s.279).

\section{Sarı Ahmed Paşa İmaret Vakfi}

Ahmed Paşa'nın 889 (1484) ve 893 (1488) yıllarına ait Arapça kaleme alınmış iki adet vakfiyesi bulunmaktadır. Bu vakfiyelerin suretleri Tapu ve Kadastro Genel Müdürlüğü, Tapu Arşiv Dairesi Başkanlığı, Vakf-1 Cedid Defterleri Fonu'nda VAYS.VC kodunda ve 205 numara ile kayıtlıdır. Ayrica vakfiyenin bir sureti de Vakıflar Genel Müdürlüğ̈̈ Arşivi'nde (VGMA) yer almaktadır $^{12}$. I. vakfiye diğerine göre oldukça kapsamlıdır. II. vakfiye ise asıl vakfiyeye zeyl niteliğindedir. II. vakfiyede vakfa ilave gelirler tahsis edilmiş ve bu gelirlerin nerelere ve nasıl sarfedileceği belirlenmiştir. Bu vakfiyenin tarihi incelendiğinde Ahmed Paşa'nın ölümünden bir kaç ay önce düzenlendiği anlaşılmaktadır.

Ahmed Paşa, Akhisar'da cami, medrese, imaret (aşevi), hamam ve hanın bulunduğu bir külliye inşa ettirmiş, bu kurumların yaşatılması için bir vakıf kurmuştur. 1484 yılında kurulan vakıf günümüzde faal olarak işlevini sürdürmektedir ${ }^{13}$.

${ }^{11} 166$ Numarall Muhâsebe-i Vilâyet-i Anadolu Defteri (937/1530)'da Edremid Kazası'nda vakfı olan Saruca Paşa ile Sarı Ahmed Paşa'nın farklı şahsiyetler oldukları belirtilmiştir. Bkz., s.277-278.

12 VGMA'da bulunan Vakfiye I, Arapça'dan Türkçe'ye çevrilmiştir. Çeviride yer isimlerinin çoğu yanlış yazılmıştır.

${ }^{13}$ Halen mülhak vakıf statüsünde olup, 2004 yılından itibaren mütevelli olarak Gülgün Aloğlu tarafından idare edilmektedir. Mülhak Vakıf, 5737 sayılı Vakıflar Kanunu'na 
Paşa, kurduğu vakfa kazandığı servetinin yanı sıra padişah II. Bayezid tarafından kendisine temlik edilen mülkleri de bağışlamıştır. Onun Akhisar, Adala (Salihli), Manisa ve Bergama kazaları ile bunlara bağlı köy ve mezra'alarda birçok arazi ve emlakı bulunmaktaydı. Bunların tümünü vakfettiği söylenemez. Temliknâmesindeki mülklerinden bazıları vakfiyesinde yer almamıştır. Bunlar arasında, Manisa'ya bağlı Burun Virancık Köyü sınırında yer alan hayvanların otladığı bir mera ile içinde değirmenlerin bulunduğu Soğukluca olarak adlandırılan bir mezra, yine Gördüs Kazası'nda Tanburî Argl Suyu üzerinde bulunan üç değirmen ile Bakır Ovası'nda Kara Kurtlu adlı köyde bulunan bir değirmen yer alıyordu.

Tablo 1: Sarı Ahmed Paşa'nın 893 (1484) Tarihli Vakfiyesi’ne Göre Vakfedilenler

\begin{tabular}{|l|l|}
\hline \multicolumn{1}{|c|}{ Vakfedilenler } & \multicolumn{1}{c|}{ Bulunduğu Yer } \\
\hline *Ketencioğlu Değirmenleri (4 adet) & Adala \\
\hline Kasım Beg Değirmenleri & $\begin{array}{l}\text { Sı̆̆ır } \\
\text { (Kırında) }\end{array}$ \\
\hline Ahmed Paşa Kervansarayı ve içindeki dükkânlar & Akhisar \\
\hline $\begin{array}{l}\text { Ahmed Paşa Hamamı ve hamamın suyu ile sulanan } \\
\text { bahçe }\end{array}$ & Akhisar \\
\hline Hamam & Edremit/Kemer Köyü \\
\hline Hamam & Marmara \\
\hline Sofuluca (Sofilice) Çiftliği & Manisa \\
\hline Çiftlik & Manisa/Köşk Pınarı \\
\hline *Çamurluca Çiftliği (Doğancı Çiftliği) & Manisa \\
\hline $\begin{array}{l}\text { *Çabaric (Çabariş) Değirmeni (Gökçe Su } \\
\text { üzerinde kurulu) }\end{array}$ & Manisa \\
\hline $\begin{array}{l}\text { *Değirmen ve içindeki Pirinç döğülen değirmen } \\
\text { odaları }\end{array}$ & $\begin{array}{l}\text { Manisa / Gürleye } \\
\text { Köyü }\end{array}$ \\
\hline Pirinç döğülen iki değirmen odası & Bozöyük \\
\hline $\begin{array}{l}\text { Büyük Ark suyu ile dönen değirmen ve içindeki } \\
\text { pirinç döğme odaları }\end{array}$ & Adala \\
\hline Büdüklü/Büdüklüce Köyü & Bergama \\
\hline Bozahâne & Bergama/Saray Avlusu \\
\hline Bağlık ve bahçelik arazi & Bergama \\
\hline
\end{tabular}

göre, mülga 743 Sayılı Türk Kanunu Medenisi’nin yürürlük tarihinden önce kurulmuş ve yönetimi vakfedenlerin soyundan gelenlere şart edilmiş vakıflara denilmektedir. Mülhak vakıf yöneticilerinde aranacak şartlar ile yardımcılarının nitelikleri Vakıflar Yönetmeliği'nde düzenlenmiştir. Vakfiyedeki şartları taşımamaları nedeniyle kendilerine yöneticilik verilemeyenler bu şartları elde edinceye, küçükler ile kısıtlılar fiil ehliyetlerini kazanıncaya ve boş kalan yöneticilik yenisine verilinceye kadar, vakıf işleri, Genel Müdürlükçe temsilen yürütülür. Bkz. http://www.vgm.gov.tr/sayfa.aspx?Id=37 


\begin{tabular}{|l|l|}
\hline Koru & Bergama /Karaiyt \\
\hline Arazi & Bergama/Çiftlik \\
\hline Arazi & Bergama/İki Çay Arası \\
\hline Bağlı ve Koruluk & $\begin{array}{l}\text { Bergama/Eminüddin } \\
\text { Mezra'ası }\end{array}$ \\
\hline Arazi & Bergama \\
\hline Tepecik Değirmeni & $\begin{array}{l}\text { Bergama/Gördük } \\
\text { Nahiyesi }\end{array}$ \\
\hline $\begin{array}{l}\text { Su değirmeni -pirinç öğ̈̈tülen-(Gökçe Su üzerine } \\
\text { kurulu ) }\end{array}$ & Manisa / Korkud Köyü \\
\hline İki Su Değirmeni & Akhisar \\
\hline *Bă̆ 30 cerib (dönüm) & Akhisar \\
\hline Marangoz iki köle & Akhisar \\
\hline 80.000 gümüş dirhem & Vakıf \\
\hline Mile/Mele Köyü & Akhisar \\
\hline *Mera & Akhisar/Mile Köyü \\
\hline Bahçe 20 cerib (dönüm) & Manisa \\
\hline
\end{tabular}

*Sultan II. Bayezid tarafindan Ahmed Paşa'ya temlik edilenler

Tablo 2: Sarı Ahmed Paşa'nın 893 (1488) Tarihli Vakfiyesi'ne Göre Vakfedilenler

\begin{tabular}{|l|l|}
\hline \multicolumn{1}{|c|}{ Vakfedilenler } & \multicolumn{1}{c|}{ Bulunduğu Yer } \\
\hline $\begin{array}{l}\text { Durmuş Değirmeni ve içinde pirinç } \\
\text { öğütülen odalar }\end{array}$ & Manisa \\
\hline Arazi 1 kıta & Bergama \\
\hline Değirmen ve içinde pirinç öğütülen odalar & Palamud \\
\hline Değirmen ve içinde pirinç öğütülen odalar & Gürleye Köyü/Manisa \\
\hline
\end{tabular}

Ahmed Paşa'nın, vakfettiği mülkler incelendiğinde epey varlıklı bir kimse olduğu anlaşılmaktadır. Sahip olduğu servetin büyüklüğü, onun Osmanlı Devleti'nde üst düzey yöneticilik makamında bulunan bir devlet adamı olabileceği fikrini desteklemektedir.

Osmanlı Devleti'nde bir yerin iskâna açılması ve şenletilmesinde, hükümdarın metruk ya da iskâna kapalı tarımsal alanları kişilere mülk olarak bağışlaması (temlik) etkili uygulamalardan biriydi. Temlik sürecinde, sultana resmen başvuru veziriazam ya da beylerbeyi gibi üst düzey makam sahiplerinin aracılığı ile gerçekleşiyordu. Temlik için başvuran kişi, çoğunlukla hayır hasenât gayesiyle yaptırdığı cami, medrese, imaret gibi sosyal ve dini kurumları yaşatmak amacıyla kurduğu vakfa, gelir kaynağı oluşturmak için bunu talep ediyordu. Hükümdarın temliknâme/mülknâme verirken, sadakât ve yararlılığa dikkat ettiği anlaşılmaktadır. Ayrıca mülknâme ile kişiye verilen arazinin sınırları özenle ve dikkatlice tespit edilirdi (İnalcık, 2000, s. 164-165). 
Osmanlı Hükümdarı II. Bayezid, Sarı Ahmed Paşa’ya bir mülkname vermiştir $^{14}$. Buna göre kendisine, daha önce ifade ettiğimiz üzere, Akhisar kazasında bir çayırlık, Burun Virancık Köyü'nde bir mera ile mezra ve bu bölgeye yakın Çamurluca olarak bilinen Doğancı Çiftliği bağışlanmıştır.

Sözü edilen mülknamede Ahmed Paşa'nın birçok değirmene sahip olduğu görülmektedir. Onun Manisa Kazası'na bağlı Gökçesu'da bir Çabaric Değirmeni bulunmaktaydı. Ayrıca mülkleri arasında, Manisa'ya bağlı Gürleye adlı köyün sınırında üç değirmen, Adala kazasında Gediz Nehri üzerinde Kettâni Ŏglu Değirmenleri diye bilinen dört değirmen, Gördüs Kazası'nda Tanburî Argı Suyu üzerinde bulunan üç değirmen ve Bakır Ovası'nda Kara Kurtlu adlı köyde bulunan bir değirmen yer almaktaydı.

Öte yandan Ahmed Paşa tarafından Sultan Mustafa'nın annesine önceden satılmış olan bir bahçe, yeniden kendisinin mülkü haline gelmiştir. Buna göre, Osmanlı hükümdarı Fatih Mehmed'in ölen oğlu şehzâde Mustafa'nın annesi Gülşah Hatun, Ahmed Paşa'dan Manisa yakınlarında bir bahçe satın almış, ancak Gülşah Hatun'un vefat etmesinden sonra bu bahçenin mülkiyeti Sultan II. Bayezid'e geçmiştir. Bundan sonra paşa, aynı bahçeyi padişah II. Bayezid'den satın almıştır. Ayrıca Akhisar'a bağlı otuz dönümlük bir bağın haracı da padişah tarafından kendisine temlik edilmiştir.

Mülknâme ile temlik edilen mezraların, bağların, bağçelerin ve değirmenlerin mülkiyeti, haraçları ile birlikte kendisine geçen paşa, bunları dilediği gibi tasarruf etme hakkına sahip olmuştur. Temlik edilen yerlerin hudutları padişahın emri doğrultusunda Manisa Kadısı tarafindan tespit edilmiş, İstanbul'a gönderilerek onaylanmıştır (Erdoğru - Bıyık, 2014, s.186).

Ahmed Paşa sözü edilen bu mülkleri, Akhisar'da kurduğu İmaret Vakfi'na bağışlamıştır. Bu vakfın gelirleri arasında Manisa Kazası içinde yer alan Köşk Pınarı Köyü de bulunmaktaydı.

1577 yılına ait Saruhan Sancă̆ Evkâf Defteri'nde yer alan bilgilere göre, Sarı Ahmed Paşa Imaret Vakfi'na ait gelir kaynakları aşağıda tablo halinde gösterilmiştir.

Tablo 3: 1577 Yılı Saruhan Sancağı Evkâf Defteri'ne Göre Sarı Ahmed Paşa İmaret Vakfı Gelirleri

\begin{tabular}{|l|l|r|}
\hline \multicolumn{1}{|c|}{ Gelir Kaynağı } & \multicolumn{1}{|c|}{ Bulunduğu Yer } & \multicolumn{1}{|c|}{$\begin{array}{c}\text { Yıllık } \\
\text { Geliri } \\
\text { (Akçe) }\end{array}$} \\
\hline Hamam & Akhisar & 5.810 \\
\hline Hamam & Marmara & 2.490 \\
\hline Hamam & $\begin{array}{l}\text { Karesi/Edremid Nahiyesi / } \\
\text { Kemer Köyü }\end{array}$ & 5.000 \\
\hline Dükkânların kirası & Akhisar & 19.105 \\
\hline
\end{tabular}

14 II. Bayezid döneminde verilen Mülknâmenin verildiğ tarihe ilişkin bir kayda rastlamadik. 


\begin{tabular}{|l|l|r|}
\hline $\begin{array}{l}\text { Dükkânların nakit } \\
\text { sermayesi }\end{array}$ & Akhisar & 3.200 \\
\hline $\begin{array}{l}\text { Mile Köyü geliri ve Akhisar } \\
\text { Çayırı }\end{array}$ & Mile Köyü/Akhisar & 7.119 \\
\hline Bağlar ve Bozahane & Bergama & 3.992 \\
\hline Büdüklüce Köyü Geliri & Bergama & 2.500 \\
\hline Dink & Boz Depe & 500 \\
\hline Mezra & Soğukluca & 500 \\
\hline $\begin{array}{l}\text { Burun Virancık'dan ayrılan } \\
\text { Çiftlik }\end{array}$ & Köşk Pınarı Köyü & 2.150 \\
\hline Ortakçıan & Köşk Pınarı Köyü & 1.200 \\
\hline Asiyâb & Bakır & 1.000 \\
\hline Asiyâb & Gördük & 1.425 \\
\hline Asiyâb-1 Ali Beg & Yeri belli değil & 2.000 \\
\hline Asiyab ve Dink & Adala Kazası'nda İne Kesri & Harap \\
& yakınında & durumda \\
\hline Asiyâb-1 Kettani & Adala & 300 \\
\hline Bağ ve Bağçe 3 dönüm & Akhisar & 450 \\
\hline Bağ ve Bağçe 20 dönüm & Manisa & 225 \\
\hline Mukataa-i Saray Havlı & Bergama & 150 \\
\hline Mukataa-i Hisarlık & Adala & 60 \\
\hline Mukataa-i Zemin & Marmara Camii & 100 \\
\hline Bağ & İne Kesri & 50 \\
\hline Toplam & & $\mathbf{5 9 . 3 2 6}$ \\
\hline
\end{tabular}

Yukarıdaki tabloya göre paşa, kurduğu vakıf için büyük bir servet bağışlamıştır. Bağışlanan köylerden elde edilen gelirlerin yanında, değirmenler, tarım arazileri ve meralar ile hamamlar, dükkânlar gibi birçok gayrimenkulden sağlanan gelirler de vakfa tahsis edilmiştir. Bu mülkler mütevelli marifetiyle kiraya verilerek işletiliyordu. Bunların büyük bir kısmı XIX. yüzyılın sonlarına kadar faal olarak işlevini sürdürmüş, kiralama yolu ile vakfa gelir sağlanmıştır (BOA, C.EV., 4539). Ancak günümüzde gelir getiren mülkleri arasında yalnızca Akhisar'daki hamam, imaret binası ve harabe halindeki han kalmıştır.

Tablo 4: 1577 Yılı Saruhan Sancağı Evkâf Defteri'ne Göre Sarı Ahmed Paşa İmaret Vakfı'nın Giderleri

\begin{tabular}{|l|r|}
\hline \multicolumn{1}{|c|}{ Harcama Kalemi } & Tutar \\
\hline Nezâret & 2 akçe (günlük) \\
\hline Tevliyet & 10 akçe (günlük) \\
\hline Kitâbet & 4 akçe (günlük) \\
\hline İmâmet & 4 akçe (günlük) \\
\hline Müezzin & 3 akçe (günlük) \\
\hline Hitâbet & 2 akçe (günlük) \\
\hline Muarrif & 1 akçe (günlük) \\
\hline
\end{tabular}




\begin{tabular}{|l|r|}
\hline Muallim & 3 akçe (günlük) \\
\hline Meşihat & 2 akçe (günlük) \\
\hline Cüz-hanân (10 nefer) & 10 akçe (günlük) \\
\hline Ferraş & 2 akçe (günlük) \\
\hline Habbâz & 2 akçe (günlük) \\
\hline Tabbâh & 2 akçe (günlük) \\
\hline Kilârî & 2 akçe (günlük) \\
\hline Câbi-i Köşk & 2 akçe (günlük) \\
\hline Câbi-i asiyâbhâ & 5 akçe (günlük) \\
\hline Câbi-i Bergama & 2 akçe (günlük) \\
\hline Gûşt & 20 akçe (günlük) \\
\hline Pirinç & 5 akçe (günlük) \\
\hline Hinta beray-1 Şorba & 3 akçe (günlük) \\
\hline Hnnta beray-1 hubz & 8 akçe (günlük) \\
\hline Hayme & 4 akçe (günlük) \\
\hline Nemek ve piyaz & 2 akçe (günlük) \\
\hline Beray-1 harc-1 müsafir & 4 akçe (günlük) \\
\hline Revgan-1 çerağ ve hasır & 2 akçe (günlük) \\
\hline Pâk-kerden âb-1 riz & 1 akçe (günlük ) \\
\hline Kendum-kûb & nim akçe (günlük) \\
\hline Harc-1 dolab & 2 akçe (günlük) \\
\hline Cihet-i neccâr ve benna & 4 akçe (günlük) \\
\hline Bahâ-i ester & 2 akçe (günlük) \\
\hline Alef-i ester & 2 akçe (günlük) \\
\hline Beray-1 râh-1 çeşme & 2 akçe (günlük) \\
\hline Hizmetkâr-1 dolab & 4 akçe (günlük) \\
\hline Meremmât-1 dekâkin & 2 akçe (günlük) \\
\hline Mirza Beg & 2.660 akçe (senelik) \\
\hline Kara Beg & 1.330 akçe (senelik) \\
\hline Emine Hatun & 652 akçe (senelik) \\
\hline Hadice Hatun & 652 akçe (senelik) \\
\hline Atiye Hatun & 1.603 aç̧e (senelik) \\
\hline Sarı Beg & 650 akçe (senelik) \\
\hline Ahmed Beg & 650 akçe (senelik) \\
\hline Süleyman Çelebi & 1.066 akçe (senelik) \\
\hline Hafsa Hatun & 532 akçe (senelik) \\
\hline Ali Çelebi & 84 akçe (senelik) \\
\hline Ahmed Beg birader-i o & 84 akçe (senelik) \\
\hline Bostan Beg birader-i o & 84 akçe (senelik) \\
\hline Sinan Beg birader-i o & 84 akçe (senelik) \\
\hline Mihri Hatun & 42 akçe (senelik) \\
\hline Safiye Hatun & 42 akçe (senelik) \\
\hline
\end{tabular}




\begin{tabular}{|l|r|}
\hline Fatıma Hatun & 42 akçe (senelik) \\
\hline Ümmi Hatun ve Haymana Hatun & 84 akçe (senelik) \\
\hline $\begin{array}{l}\text { Osman Beg ve Mehmed Beg ve Fatıma } \\
\text { Hatun }\end{array}$ & 84 akçe (senelik) \\
\hline Hüseyin ve Ali & 218 akçe (senelik) \\
\hline Fatıma Hatun & 54 akçe (senelik) \\
\hline Be-cihet-i evlâd-1 Hümâyûn Hatun & 408 akçe (senelik) \\
\hline Hasan Ali Çelebi & 289 akçe (senelik) \\
\hline Sitti Hatun & 178 akçe (senelik) \\
\hline Mehmed & 654 akçe (senelik) \\
\hline Sitti Hatun & 178 akçe (senelik) \\
\hline Aynî Hatun & 80 akçe (senelik) \\
\hline Ahmed Beg & 160 akçe (senelik) \\
\hline Nuh Beg & 160 akçe (senelik) \\
\hline Be-cihet-i evlâd-1 Bustan Beg & 400 akçe (senelik) \\
\hline Be-cihet-i evlâd-1 Rabia Hatun & 1.600 akçe (senelik) \\
\hline
\end{tabular}

Tablo 4'te belirtildiği gibi, harcamalar günlük ve senelik olarak yapılmıştır. Vakfin yıllık muhasebesinde gelir ve gider rakamlarının hemen hemen eşit olduğu anlaşılmaktadır ${ }^{15}$. Öte yandan vakfiyede belirtildiği üzere harcamalar sonucunda arta kalan para, Ahmed Paşa'nın evlâdına verilecektir. Neslin inkırazı halinde ise bu para vakfa dâhil edilecektir.

\section{Sarı Ahmed Paşa İmaret Vakfındaki Görevliler}

Vakfiye I'de belirtildiğine göre, vâkıfın sağlığında kendisi, kendisinden sonra ise evladı ve neslinden gelenlerden mütevelli seçilecektir. Bu görevde bulunanlar vakfın gelirlerini helal yollardan en iyi şekilde değerlendirecektir. Bununla birlikte mütevelli olacak kişilere günlük 8 akçe ücret verilmesi kararlaştırılmıştır. Ancak Vakfiye II'de bu ücrete 2 akçe daha ilave edilerek mütevellinin günlük 10 akçe ücret alacağ 1 belirlenmiştir. Bundan başka İmaret Vakfi'nda, cami görevlilerinden imam, hatib ve müezzinin vazifeleri ve alacakları ücretler de tayin edilmişti. Görevliler arasında şeyh, nâzır, kâtib, müderris, muallimin yanı sıra imarette (aşevinde) bir habbaz (ekmekçi), bir aşçı, bir kilerci, bir ferraş (temizlikçi) da bulunmaktaydı. Ayrıca üç câbi (tahsildar) ve iki meremmetçi (tamirci) de çalışıyordu.

Tablo 5: Vakfiye I'de Yer Alan Görevliler/Harcama Kalemleri ve Tahsis Edilen Ücretleri

\begin{tabular}{|c|c|c|}
\hline $\begin{array}{c}\text { Görevli / Harcama } \\
\text { Kalemi }\end{array}$ & Görevi / Ne Amaçla Harcandığı & $\begin{array}{c}\text { Tahsis } \\
\text { Edilen Ücret } \\
\text { (günlük } \\
\text { akçe) }\end{array}$ \\
\hline
\end{tabular}

15 Günlük harcamaların toplamı 125.5 akçe, senelik harcamaların tutarı ise 14.804 akçedir. Günlük harcamanın yıllık tutarı olan 44.427 akçe ile yine yıllık ödenen 14.804 akçenin toplamı 59.231 akçedir. Bu da vakfın bir yıllık gideridir. 


\begin{tabular}{|c|c|c|}
\hline Mütevelli & Tevliyet/vakfin idaresi & \\
\hline İmam & İmamlık ve 1 cüz Kur'an okuma & 5 \\
\hline Hatîb & $\begin{array}{l}\text { Hutbe okumak ve } 1 \text { cüz Kur'an } \\
\text { okuma }\end{array}$ & 3 \\
\hline Müezzin & Müezzinlik ve 1 cüz Kur'an okuma & 4 \\
\hline Cüz-hanân (10 kişi) & 1 cüz Kur'an okuma (Her biri için) & 1 \\
\hline 4 kişi & $\begin{array}{l}\text { "Lâ İlahe illallah" } 1000 \text { defa (her biri } \\
\text { için) }\end{array}$ & Yarım akçe \\
\hline Nâzır & Nezaret & 3 \\
\hline Kâtib & Kitabet, gelir ve giderin yazılmas 1 & 3 \\
\hline Muallim & Çocuklara Kur'an öğretmek & 3 \\
\hline Șeyh & Meşihat & 2 \\
\hline Habbaz (ekmekçi) & Ekmek pişirmek & Belirtilmemiş \\
\hline Așç1 & Yemek pişirmek & 2 \\
\hline Kilerci & Mutfak işleri & 2 \\
\hline Ferraş & Temizlik işleri & 2 \\
\hline Câbi (1) & Köşk Pınarı köyündeki geliri toplama & 2 \\
\hline Câbi (1) & Değirmenlerin hâsılatını toplama & 3 \\
\hline Köle (2) & İmaretin her türlü tamir işleri & 2 \\
\hline Buğday 1 kile $^{16}$ & Ekmek & Belirtilmemiş \\
\hline Buğday ögütücü & Mutfakta pişecek buğdayı öğütme & Yarım akçe \\
\hline Taze Et & Yemekte kullanılmak üzere & 20 \\
\hline Pirinç & Çorbada kullanılmak üzere & 5 \\
\hline Kendum & Pişirilecek buğday & 3 \\
\hline Odun & Yemek pişirmek için yakacak & 4 \\
\hline Soğan ve tuz & Yemek için kullanılacak & 2 \\
\hline Ziyafet Bedeli & $\begin{array}{l}\text { Misafirlere ikram için, bal, ekşi, } \\
\text { meyve vs. }\end{array}$ & 4 \\
\hline $\begin{array}{lll}\begin{array}{l}\text { Hasır, } \\
\text { yağlar }\end{array} & \text { Çerağ } & \text { ve } \\
\end{array}$ & İmarette kullanım & 2 \\
\hline Ester (Katır) & Dolap işinde kullanılacak & 2 \\
\hline Saman ve Arpa & Ester için & 1 \\
\hline $\begin{array}{l}\text { Temizlik tamir, } \\
\text { bakım }\end{array}$ & $\begin{array}{l}\text { Tuvaletlerin temizliği ve dükkânların } \\
\text { 1slahı }\end{array}$ & 1 \\
\hline Tamir ve Bakım & Su yolunun 1slah1 ve bakım1 & 2 \\
\hline Hizmetli ve bakım & $\begin{array}{l}\text { Su yolunda çalişacak hademe ve } \\
\text { diğer işler }\end{array}$ & 4 \\
\hline $\begin{array}{l}\text { Vâkıfin } \quad \text { erkek } \\
\text { evladına }\end{array}$ & Vakfiye şartı & 10 \\
\hline Vâkıfın kız evladına & Vakfiye şartı & 2 \\
\hline
\end{tabular}

${ }^{16}$ Manisa Kilesi olarak belirtilmiştir. 


\section{Vakfiye I'deki Şartlar}

Vâkıf, her gün camide 1 cüz Kur'an-1 Kerim okunmasını istemiştir. Bunun için camiye sürekli gelenler ve Kur'an tilavetini bilenler arasından olmak üzere, imam, müezzin ve hatibin de içinde yer aldığ 10 kişilik bir cüz-hânân oluşturulacak, her biri günde bir cüz Kur'an okuyacak ve bunun sevabını da vakıf sahibinin ruhuna hibe edeceklerdir. Buna mukabil kendilerine günlük 1'er akçe ücret tahsis edilecektir. Ayrıca 4 kişilik zikir grubu, her gün mahallede toplanıp, biner defa "Lâ ilâhe illallâh" diyecektir. Bunun karşılığında her birine günlük yarım akçe verilecektir.

İmaret'de (Aşevi) yemek için kullanılacak malzemeler ve bunların temini, pişirilmesi, dağıtılması ayrıntılı bir şekilde belirtilmiştir. Pişirilecek taze et için günlük 20 akçe, çorbada kullanılacak pirinç için günlük 5 akçe ayrılmıştır. Vakfiye II'de bu tahsisat arttırılmıştır. Ayrıca mütevellinin vereceği karar ile pirinç pilavı, ekmek yapımı ve diğer yemeklik malzemeler için de günlük ayrılan pay yükseltilebilecektir. Vakfiyede belirtilen esaslar doğrultusunda imarette et, pirinç pilavı, çorba ve taze ekmek pişiriliyordu. İki öğün pişirilen yemekte günlük etin yarısı ve çorba için ayrılan pirincin yarısı sabah, kalan yarısı da akşam için kullanılıyordu. Ekmeğin ağırlığı 75 dirhem olarak belirlenmişti. Fakirlere yemek ve ekmeğin dağıtımında belli bir ölçek ve usûle göre hareket ediliyordu. İki fakire bir tas çorba ve birer ekmek şeklinde dağıtım yapılıyordu. İmarette yalnızca fakirler doyurulmuyor aynı zamanda misafirler için de zaman zaman ziyafetler düzenleniyordu. Bunun yanı sıra medrese öğrencilerine ücretsiz yemek yeme imkânı da sağlanıyordu. Tüm bunlar için vakfiyede ayrıca günlük ödenek tahsis edilmiştir. Mesela misafirler için verilecek ziyafette lezzetli yemeklerin yapılması, çeşitli meyvelerin hazırlanması, bal, ekşiler ve sirkeler için de günlük 4 akçe ayrılması kararlaştırılmıştır.

İmaretin günlük ihtiyaçlarından odun, soğan, tuz, yağ, hasır, çerağ ve sâir malzemeler için ayrıca tahsisat yapılmıştı. Mütevellinin kararı ile bu malzemeler için belirlenen para miktarı da arttırılabilecekti (Vakfiye II). Öte yandan vakfın taşımacılık işlerinde kullanılmak üzere bir katır (ester) vakfedilmişti. Ayrıca mutfağın ve handaki dükkânların ıslahı ve çatılarının onarılması için de para ayrılmıştı. Bunun yanında tuvaletin temizliği de düşünülmüş, tedbirler alınmıştı.

Ahmed Paşa'nın Akhisar'ın ihyasında büyük pay sahibi olduğunu gösteren en önemli icraatlarından birisi de şehrin içme suyu problemini halletmesiydi. Akhisar'ın XV. yüzyıldaki harap görüntüsü ve su yollarının tıkanarak kullanılamaz hale gelmesi üzerine paşa, inşa ettirdiği cami, medrese, hamam ve han gibi yapıların ihtiyacı olan suyun temini için, kaynak arayışında olmuş, şehrin kuzeyinde yeni su kaynakları üzerinde kemerler yaptırmış ve isale hattıyla bu suyu şehrin merkezine ulaştırmıştır (Vakfiye II). Bu hizmetin devam ettirilmesi için su yolunun ıslahı için günlük 2 akçe ayrılmış, ayrıca burada 
çalışacak hademenin ücreti ve diğer masrafları için günlük 4 akçe tayin edilmiştir.

Tablo 6: Vakfiye II'de Yer Alan Görevliler/Harcama Kalemleri ve Tahsis Edilen Ücretleri

\begin{tabular}{|l|l|r|}
\hline $\begin{array}{c}\text { Görevli / } \\
\text { Harcama } \\
\text { Kalemi }\end{array}$ & \multicolumn{1}{|c|}{ Görevi / Ne Amaçla Harcandığı } & $\begin{array}{c}\text { Tahsis Edilen } \\
\text { Ücret (günlük } \\
\text { akçe) }\end{array}$ \\
\hline Müderris & Ders vermek & 12 \\
\hline Talebe & Medresede kalan talebelere burs & 5 \\
\hline İmam & İmamlık (Marmara'daki cami) & 300 (senelik) \\
\hline Müezzin & Müezzinlik (Marmara'daki cami) & 300 (senelik) \\
\hline Hatîb & Hitabet (Marmara'daki cami) & 100 (senelik) \\
\hline İmam & İmamlık (Edremid/Kemer'deki cami) & 300 (senelik) \\
\hline Müezzin & Müezzinlik (Edremid/Kemer'deki cami) & 300 (senelik) \\
\hline Hatîb & Hitabet (Edremid/Kemer'deki cami) & 100 (senelik) \\
\hline İmam & İmamlık (Ayazmend'deki cami) & 300 (senelik) \\
\hline Müezzin & Müezzinlik (Ayazmend'deki cami) & 200 (senelik) \\
\hline Kızı Hadice & Vakfiye şartı & 2 \\
\hline Câbi & Bergama'daki evkaf için & 5 \\
\hline
\end{tabular}

Ahmed Paşa'nın, vakfiyesinden Manisa, Bergama ve Palamud'daki değirmen ve arazilerini bağışladığı, Akhisar'da imaretinin yanında bir de medrese inşa ettirdiği ve burada tefsir, fikıh, hadis başta olmak üzere tüm ilimlerin okutulduğu anlaşılmaktadır. Yine bunun yanında aynı vakfiyede Marmara Kasabasi'nda bir cami, Ayazmend'de bir mescid ve Edremit Kazası'na bağlı Kemer Köyü'nde de bir camiden bahsedilmektedir. Bahsedilen bu camilerde görev yapan imam, müezzin ve hatip gibi görevlilerin maaşları kurulan vakıf tarafından ödeniyordu. Marmara'da ve Edremid'e bağlı Kemer Köyü'nde inşa ettirdiği camilerdeki görevliler için senelik 700'er akçe, Ayazmend'deki mahalle mescidi için de senelik 500 akçe tahsis edilmiştir.

Vakfiye II'de İmaret Vakfı'nın bazı görevlileri ile ilgili yeni düzenlemeler yapılmıştır. $\mathrm{Bu}$ doğrultuda görevlilerin ücretlerinde artışlar yapılmıştır. Ayrıca vakfiyede paşanın Hadice isimli bir kızından söz edilmektedir. $\mathrm{Bu}$ kızına da diğer kızlarına verildiği gibi günlük 2 akçe ücret tahsis edilmiştir.

\section{Sarı Ahmed Paşa'nın Yaptırdığı Eserler}

Ahmed Paşa, Akhisar'da içerisinde cami, mektep, medrese, imaret (aşevi), hamam ve han'ın bulunduğu bir külliye yaptırmıştır. Bu yapılar topluluğu ya da geniş anlamıyla imaret, Akhisar'ın büyüyüp gelişmesinde şüphesiz etkili olmuştur. Esasen Türk-İslam şehirlerinin imaretler etrafinda kurulup gelişmesi yaygın bir uygulama olarak karşımıza çıkmaktadır. Onun Akhisar ile birlikte Marmara'da (Göl Marmara), Edremid Kazası'na tâbi Kemer Köyü'nde ve Ayazmend'de inşa faaliyetinden söz etmek mümkündür. Bir kısmı 
yok olan bu eserlerden yalnızca Akhisar'da cami, imaret, han ve hamam günümüze kadar varlığını koruyabilmiştir.

Manisa tarihi ve vakıfları ile ilgili 1950'lerde çalışmalar yapan İbrahim Gökçen ${ }^{17}$, Akhisar'daki Sarı Ahmed Paşa'nın yaptırdığı eserler ve kurduğu imaret vakfı ile ilgili bir takım bilgiler vermektedir. Gökçen, Paşa Cami'nin bakımlı ve iyi durumda olduğunu belirtir. Caminin doğu tarafında yıkılıp tekrar yapılan bir imaretten ve yine bu caminin kuzeyinde, faal durumdaki bir hamamdan bahseder. Ayrica caminin batısında yer alan harap durumdaki bir handan da söz eder. Günümüzde bu yapıların durumu da hemen hemen aynıdır. Cami, imaret ve hamam faal ve sağlam durumda iken, han harap vaziyettedir.

\section{A) Camiler}

\section{Paşa Cami (Akhisar)}

İmaret içinde yer alan eserlerden biri olan Paşa Cami'nin yapılış tarihi tam olarak belli değildir. 1484 yılından önce yapıldığı bilinmektedir ${ }^{18}$. Caminin günümüzde üzerinde bulunan kitabesi ise bir tamir kitabesidir. Kitabede:

"Didim özge tarih şerhi bu hayra

Bi-hamdillah cami oldu tamir sene 1005" yaz1lidır.

Ebced hesabıyla tarih düşürülmüştür. H. 1005 (1596-97) yılında caminin tamir edildiği anlaşılmaktadır. XVII. yüzyıl seyyahı Evliya Çelebi Akhisar'ı anlatırken Paşa Cami'inden de söz eder ${ }^{19}$.

Cami'nin kuzey istikametinde bir hazire yer almaktadır. Paşanın kabri ile birlikte 15 adet kitabeli kabir taşı daha vardır. 1950’lerde bu mezar taşları ile ilgili araştırmalar yapan M. Müderrisoğlu, Sarı Ahmed Paşa'nın ailesi ile ilgili bir ize rastlamadığını ifade eder. Sadece Ayşe bint-i İbrahim Ağa'ya ait bir mezar taşında ${ }^{20}$ paşaya bir atıf olduğundan bahseder (Müderrisoğlu, 1956, s. 24).

17 İbrahim Gökçen, Manisa tarihi ile ilgili çalışmalar yapan bir diğer araştırmacı M.Çağatay Uluçay'a dayandırdığı bilgilere göre, Sarı Ahmed Paşa'nın İkinci Murad ve Fatih devrinde yaşamış olduğunu ve vakfiyesinde bahsedilen mülklerinin bir kısmını satın aldığı ve bir kısmının da İkinci Murat ve oğlu Fatih Sultan Mehmet tarafından kendisine temlik edildiğini ifade etmektedir. Bkz. İbrahim Gökçen, Manisa Tarihinde Vakıflar ve Hayırlar II, İstanbul 1950, s.118.

${ }^{18}$ Caminin yapılış tarihi 1469 olarak verilse de kaynak gösterilmemektedir.

${ }^{19}$ Evliya Çelebi, Paşa Cami'sinden bahsederken "kargir minareli ve üç kargir kubbeli ve üç kapu ve hareminin ortasında ve abdest havuzu ve hareminin etrafinda medrese hücreleri cümle bu imaretler kurşun ile mestur camii ruşen abâd bibedeldir ve kıble kapusu üzere celi hattı ile tahrir olunan tarih budur. Didim özge tarih şerhi bu hayra, Bihamdillah cami oldu tamir sene 1005" olarak ifade eder. Seyahatnâme, İstanbul 1935, IX, s.61.

${ }^{20} \mathrm{Bu}$ mezar taşında "Eyledi Dar-1 fenâdan irtihal Ayşe kadın bint-i İbrahim Ağa, Irk1 tâhir sahibi ismet idi ceddi alâsı Ahmed Paşa" yazılıdır. 


\section{Marmara Cami (Marmara Kasabası)}

$\mathrm{Bu}$ cami ile ilgili bilgiler vakfiye II'de yer alır. Buna göre, Marmara Kasabası'nda paşanın bina ettiği bu caminin imam, hatîb ve müezzinine senelik 700 akçe tahsis edilmiştir. Öte yandan 1577 yılı Saruhan Sancağı Evkaf Defteri'nde, Ahmed Paşa Vakfi'nın gelirleri arasında "mukataa-i zemin-i cami-i Marmara" ifadesiyle bir gelir zikredilir (Erdoğru - Bıyık, 2014, s.186). 1488 y1lından önce inşa edildiğini bildiğimiz cami günümüze ulaşmamıştır.

\section{Cami (Kemer)}

1488 yılından önce inşa edilmiştir. Vakfiye II'deki bilgilere göre Ahmed Paşa Kemer'de tesis ettiği caminin imamlık, müezzinlik ve hitabet görevlileri için senelik 700 akçe ayırmıştır. 300 akçe imama, 300 akçe müezzine ve 100 akçe de hatîbe verilecektir. Edremid Kazası'na bağlı bir köy olan Kemer'de paşanın bir de hamamı da yer almaktaydı. Bu hamam,1577 yılında senelik 5.000 akçe kira bedeli ile İmaret Vakfı'nın gelir kaynakları arasındaydı.

\section{Mescit/Cami (Ayazmend)}

Ayazmend'de kendi ismiyle anılan Ahmed Paşa Mahallesi'nde bir mescid yaptırmıştır. 1488 yılından önce yapıldığı anlaşılan mescit için senelik 500 akçe ayrılmıştır. Bunun 300 akçesi imama, 200 akçeside müezzine tahsis edilmiştir.

\section{B) Hamamlar}

\section{Paşa Hamamı (Akhisar)}

Ahmed Paşa'nın Akhisar'da inşa ettiği külliye içinde yer alan hamamın yapılış tarihi ile ilgili kesin bir bilgiye sahip değiliz. Zira hamamın günümüze ulaşan bir kitabesi de mevcut değildir. 1484 yılına ait vakfiyede külliyedeki diğer yapılar ile beraber zikredilmiştir. Mimari özellikleri de düşünüldüğünde bu hamamın XV. yüzyılın ikinci yarısının ortalarında cami, imaret ile birlikte eş zamanlı inşa edilmiş olması muhtemeldir. Çifte hamam olarak planlanmış olan hamamın erkekler bölümü güney cephesinde, kadınlar bölümü ise kuzey kısmındadır (Ünalan, 1998, s.84). Restore edildikten sonra günümüzde faal olarak kullanılmakta ve İmaret Vakfı'nın en önemli gelir kaynaklarından birini oluşturmaktadır.

\section{Ahmed Paşa Hamamı (Marmara)}

Ahmed Paşa, Akhisar'daki hamamın yanı sıra kurduğu vakfa gelir sağlamak amacıyla Marmara Kasabası'nda (Göl Marmara) da bir hamam inşa ettirmiştir. Hamamın inşa kitabesi olmamakla birlikte yapılış tarihi ile ilgili mesnetsiz değişik tarihler verilmektedir. Vakfiye I'de söz edilmesi, yapılış tarihinin 1484 'den önce olduğunu ortaya çıkarmaktadır. Bu hamam da çifte hamam olarak inşa edilmiştir. Günümüzde ise kullanılmamaktır.

\section{Hamam (Kemer)}

Paşa, Karesi vilayetine bağlı Edremid Kazası içinde yer alan Kemer Köyü'nde bir hamam ve bir cami inşa ettirmiştir. Eserler, 1488 y1lından önce yapılmıştır. Günümüze kadar ulaşmayan hamamın, 1530 ve 1577 yıllarına ait 
arşiv vesikalarından mali durumu ile ilgili çeşitli bilgilere sahip olsak da nasıl yok olduğu hakkında kesin bir bilgiye sahip değiliz.

\section{C) Medrese/Mektep \\ 1. Taș Medrese}

Akhisar'daki külliye içerisinde yer alan medreseyle ilgili ilk bilgi Vakfiye II'de geçmektedir. Buna göre, Akhisar'daki İmaretin yanında yaptırılan medresede tefsir, hadis, fikıh başta olmak üzere bütün ilimler okutulması amaçlanmıştır. Bunun için, ilim ve takva sahibi bir müderrisin burada görev yapacağı ve günlük 12 akçe ücret alacağı belirtilmiştir. Ayrıca burada öğrenim gören öğrencilere günlük 5 akçe burs verilmesi de kararlaştırılmıştır.

Medresenin yapılış tarihi ile ilgili kesin bir bilgi yoktur. Ancak 1488 y1lı öncesinde inşa edilmiştir. Günümüzde tamamen yok olan medresenin bulunduğu yer ile ilgili bilgiler veren M. Müderrisoğlu, halk arasında Taş Medrese olarak anılan bu medresenin kalıntılarının bulunduğu araziyi belediyenin istimlâk ettiğini daha sonra da bazı kişilere sattığını ifade etmektedir (Müderrisoğlu, 1956, s.29-30).

\section{Mektep(Sıbyan Mektebi)}

Osmanlı Devleti'nde “Darü't-talim, darü'l-ilm, muallimhâne, mahalle mektebi, taş mekteb, mekteb-i ibtidaiyye" gibi isimlerle anılan sıbyan mektebi temel eğitim kurumlarındandır (Baltacı, 2004, s.6). Bu okullar her mahalle ve köyde mevcut olmakla birlikte genellikle camilerin yanında inşa edilmişlerdir. Bunlar, varlıklı hayırseverler tarafından vakıflar yoluyla kurulur ve yaşatılırdı (Akyüz, 1985, s.71).

Sibyan mektepleri genellikle ahşap ve kâgir yapılar şeklinde tek odalı olarak inşa edilmişlerdir. Ahmed Paşa tarafından Akhisar'da imaret bünyesinde bir mektep yaptırıldığı ve buraya bir muallim tayin edildiği anlaşılmaktadır. Mektebin yapılış tarihi 1484 yılı öncesidir. Vakfiye I'de muallimin sâlih ve dindar bir Müslüman kimse olması şart koşulmuştur. Ayrıca çocuklara Kur'an-1 Kerim öğretmesi karşılığında kendisine günlük 3 akçe ücret verilmesi kararlaştırılmıştır.

Mektebe yeni bir muallim tayin edilmesi ile ilgili H. 19 Safer 1218 (10 Haziran 1803) tarihli berattan, buradaki eğitimin XIX. yüzyılda da devam ettiği anlaşılmaktadır $^{21}$.

\section{D) Han (Akhisar)}

Akhisar'da Paşa Hanı olarak da anılan ve külliye ile birlikte yaptırılan han $^{22}$, caminin batı yönünde inşa edilmiştir. Yapılışı tarihi 1484 yılından

\footnotetext{
${ }^{21}$ BOA, C.MF, 4788'de yer alan 19 Safer 1218 tarihli atama beratında "Liva-i Saruhan'da vâki medine-i Akhisar-1 Saruhan'da Sarı Ahmed Paşa nevverallahû merkaduhû sâhibü'l-hayrâtın bina eylediği mektebde ba-berat-1 âlişan-1 hâkânî yevmi 3 akçe vazife ile muallim-i mekteb olan Şeyh Mustafa alil ve talim-i sıbyana iktidar kalmayub mekteb-i mezburun hizmet-i lâzımesi muattal olmağın kendi hüsn-i rızasıyla yerine erbab-1 istihkakdan işbu bâis-i arz-1 ubudiyyet Hafiz Süleyman bin Mustafa Halife her vechle layık..." ifadesinden anlaşılmaktadır.
} 
öncedir. Günümüzde harap halde bulunan han restore edilmeyi beklemektedir. Vakfiye I'de handa bulunan dükkânlar ile ilgili bir takım tedbir kararları alınmıştır. Tamir ve ıslahı, özellikle çatılarının yapılması için ödenek tahsis edilmiştir. Dükkânlar, vakıf için önemli bir gelir kaynağı olduğundan tamir ve bakımı önemliydi. Tamir işleri için iki köle vakfedilmişti. Dükkân kiralarından elde edilen gelir, 1576-77 yıllarına ait vakfın toplam gelir kaynakları içinde büyük bir yekûn oluşturuyordu. Senelik 59.326 akçelik toplam gelirin yaklaşık 1/3'ü olan 19.105 akçe, Akhisar'daki dükkânların kiralarından elde ediliyordu (Erdoğru - Bıyık, 2014, s.186).

\section{İmaret (Așevi)}

1484 yllında tanzim edilen vakfiyede belirtilen ve külliyedeki diğer yapılar ile birlikte inşa edilen imarette, (aşevi) fakirlerin ve muhtaçların yeme içme ihtiyacı karşılanmaktadır. İslam dini ve geleneklerine göre fakîrlerin doyurulması, ihtiyaçlarının karşılanması dinî ve sosyal sorumluluklardandır. $\mathrm{Bu}$ açıdan İslam dünyasında tesis edilen pek çok vakfin bünyesinde aşevleri yer almıştır. Ahmed Paşa'nın Akhisar'da yaptırdığı imaret, bu doğrultuda hizmet ederek, günümüze kadar ulaşmıştır.

İmaret binası, bilinmeyen bir tarihte yıkılmıştır. Bugünkü bina, 1863-64 yıllarında Paşa Cami'sinin yanına yeniden inşa edilmiştir. Binanın yeniden yapılması, Ahmed Vefik Paşa'nın Anadolu Müfettişliği görevinde, Bursa ve Balıkesir (Karesi) bölgesini teftiş ettiği dönemde alınan karar üzerine gerçekleşmiştir (Ünalan, 1998, s.118; Müderrisoğlu, 1956, s.29).

İmarette fakirlere hizmet edilmesinin yanında, misafirler de buradan istifade ediyordu. Hâlâ vakfin mütevellisi olan Gülgün Aloğlu'dan aldığımız bilgiye göre, günümüzde imaret binası bir derneğe kiralanmış, amacına uygun bir şekilde hizmetine devam etmektedir.

\section{SONUÇ}

Sarı Ahmed Paşa yaptırdığı külliye ve kurduğu vakıf ile Akhisar'ın imarında önemli bir pay sahibidir. Saruhanoğulları Beyliği'nin Osmanlı Devleti egemenliğine girmesiyle Akhisar kasabasının gelişmesi, ihtiyaç duyulan sosyal, dinî ve iktisadî yapıların inşası ile mümkün olabilmiştir. Hayırseverler kurdukları imaret vakfı ile şehirlerin gelişmesinde etkili olmuşlardır. Ahmed Paşa, XV. yüzyılda Akhisar'da yaptırdığı cami, mektep, medrese, imaret, han, hamam gibi eserleri ihtiva eden külliyesini, kurduğu vakıfla yaşatmış, insanlığın hizmetine sunmuştur. 530 yıl önce kurulan vakıf sayesinde bu eserlerin bir kısmı günümüze ulaşmış, hayır hasenat faaliyetleri ile topluma hizmet etmeyi sürdürmüştür.

Osmanlı Devleti'nde II. Bayezid devrinin önemli devlet adamlarından olan Sarı Ahmed Paşa, gösterdiği yararlılık ve sadakât ile padişahın takdirine mazhar olmuş değerli bir şahsiyettir. XV. yüzyılda yaşamış bir diğer devlet

${ }^{22}$ Kervansaray olarak da anılmaktadır 
adamı Saruca Paşa ile karıştırılmamalıdır. Nitekim arşiv vesikalarından her iki paşanın ayrı şahsiyetler olduğu anlaşılmaktadır.

Padişahın kendisine temlik ettiği mülkler ile birlikte epey servet sahibi olan Ahmed Paşa, günümüzde Batı Anadolu Bölgesi'nde yer alan Manisa, Akhisar, Göl Marmara, Bergama, Edremit, Altınova ve yöresinde birçok mülkün sahibiydi. 1488 yılında vefat eden paşa, Akhisar'da yaptırdığı caminin haziresinde medfundur.

Kendisinin 1484 ve 1488 yıllarına ait iki vakfiyesi bulunmaktadır. Yaptırdığı eserler, sadece Akhisar'da değil, Göl Marmara, Edremit ve Altınova'da da bulunmaktaydı. Ancak Akhisar'dan başka diğer yerlerdeki eserleri günümüze ulaşmamıştır.

Beş asırdan fazla bir geçmişe sahip olan Sarı Ahmed Paşa İmaret Vakfi, günümüzde mülhak vakıf statüsünde olup, vâkıfın soyundan gelenler tarafından idare edilmektedir. Bugüne gelindiğinde sahip olduğu gelir kaynaklarının büyük bir bölümü kaybolmuş durumdadır. Geçmişte uygulanan yanlış politikalar ve duyarsızlıklar neticesinde pek çok vakıf eseri tahribata maruz kalmıştır ki bundan Ahmed Paşa Vakfı da nasibini almıştır.

Akhisar'ın tarihi ve kültürel mirasının korunmasına ve yaşatılmasına bu türden çalışmaların önemli katkı sağlayacağı muhakkaktır. Sarı Ahmed Paşa gibi hayırseverlerin hak ettikleri değerde ila-nihaye hayırla yad edilmesi ve eserlerinin yaşatılması, kaybolanların yeniden ortaya çıkarılması konusunda başta yerel yönetimler olmak üzere bilim adamlarına ve araştırmacılara önemli görevler düşmektedir.

\section{ARŞIV KAYNAKLARI}

\section{KAYNAKLAR}

A) Tapu ve Kadastro Genel Müdürlüğü, Tapu Arşiv Dairesi Başkanlığı (TKGMA)

H. 1 Rebiülevvel 889 Tarihli Sarı Ahmed Paşa Vakfiyesi, TKGMA, Vakf-1 Cedid Defterleri, VAYS.VC, No:205.

H. Evâhir-i Receb 893 Tarihli Sarı Ahmed Paşa Vakfiyesi, TKGMA, Vakf-1 Cedid Defterleri, VAYS.VC, No:205.

H. Evâil-i Şevval 1059 tarihli Abdurrahman Efendi'ye Ait Vakfiye, TKGMA, Vakf-1 Cedid Defterleri, VAYS.VC, No:205.

B) Başbakanlık Osmanlı Arşivi (BOA)

BOA, C.EV., Gömlek No: 3065, Dosya No: 62

BOA, C.EV., Gömlek No: 2312, Dosya No: 47

BOA, C.MF., Gömlek No: 4788, Dosya No: 46

BOA, C.EV., Gömlek No: 4539, Dosya No: 91

BOA, C.EV., Gömlek No: 23390, Dosya No: 462

BOA, İE.EV., Gömlek No: 5273, Dosya No: 47

C) Vakıflar Genel Müdürlüğü Arşivi (VGMA) 
H. 1 Rebiülevvel 889 Tarihli Sart Ahmed Paşa Vakfiyesi Tercümesi, VGMA, Defter No:590/225/191

\section{ARASTIRMA VE İNCELEME ESERLERİ}

166 Numaral Muhasebe-i Vilâyet-i Anadolu Defteri (937/1530), (1995), Devlet Arşivleri Genel Müdürlüğü, Osmanlı Arşivi Daire Başkanlığı Yayınları Ankara.

AKYÜZ, Yahya (1985), Türk Eğitim Tarihi, Ankara.

BALTACI, Cahit (2004), "Mektep", (Osmanlilar'da Mektep), DIA, 29, s.6-7.

ERDOĞRU, M. Akif - BIYIK, Ömer (2014), Defter-i Evkâf-ı Livâ-i Saruhan (Metin ve Inceleme), TKGM Yay. Ankara.

EMECEN, Feridun (1989), "Akhisar", DİA, 2, s. 236-237.

EVLIYA ÇELEBİ (1935), Seyahatnâme, C.IX, İstanbul İstanbul.

GÖKÇEN, İbrahim (1950), Manisa Tarihinde Vakıflar ve Hayırlar II,

İNALCIK, Halil (2000), Osmanl Imparatorluğu'nun Ekonomik ve Sosyal Tarihi C.1, 1300-1600, (Çev. Halil Berktay), İstanbul.

MÜDERRİSOĞLU, Mehmet E. (1956), Akhisarlı Türk Büyükleri ve Eserleri, İzmir.

ÜNALAN, H. Sibel (1998), “Akhisar ve Göl Marmara'daki Türk Anıtları", Yayımlanmamış Yüksek Lisans Tezi, E.Ü. Sosyal Bilimler Enst. Sanat Tarihi A.B.D. , İzmir

YÜKSEL, Hasan (2012), "Vakfiye" (Türk ve Osmanlı Tarihi), DIA, s.467-469. 


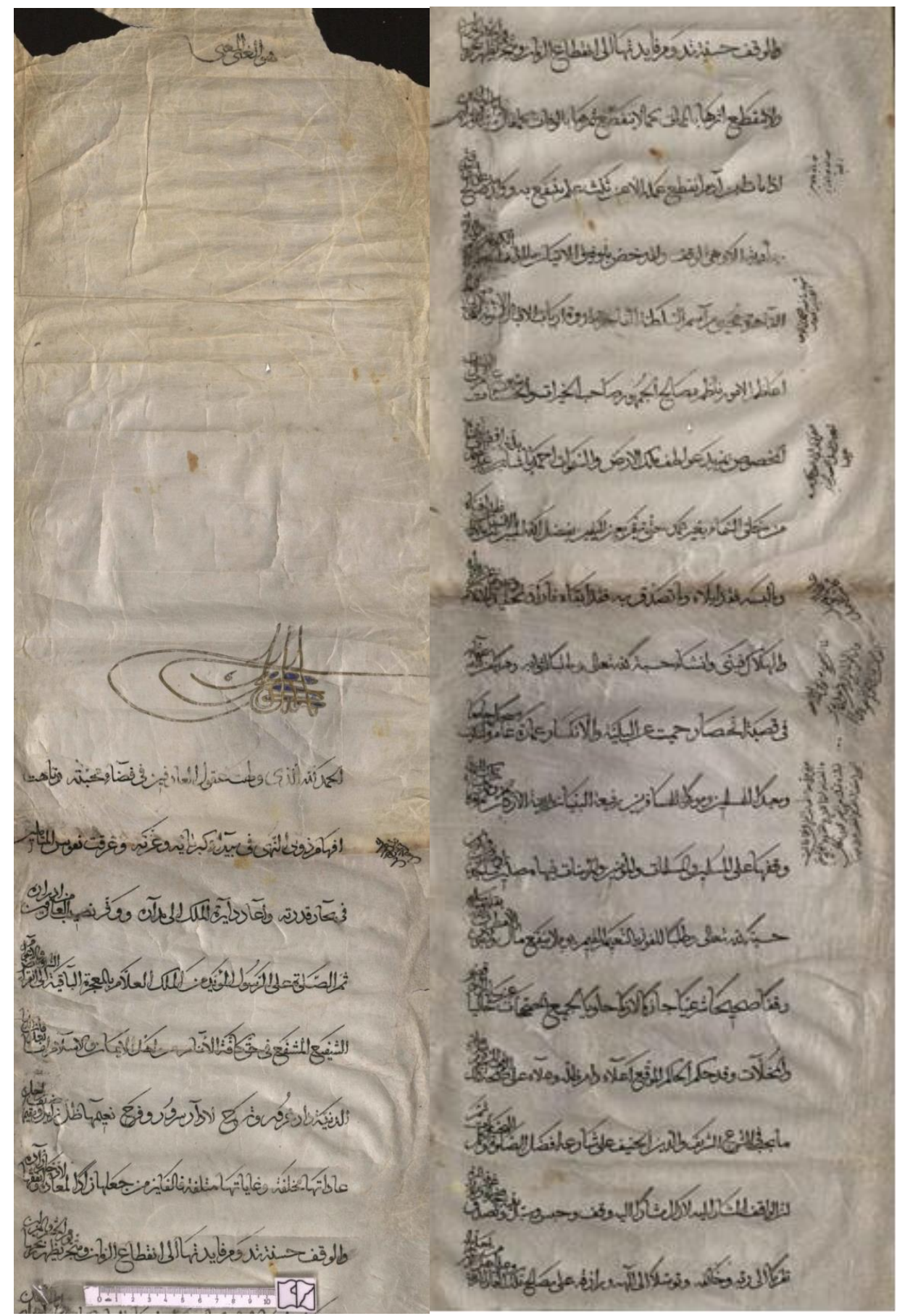

Sarı Ahmed Paşa'nın 889 Tarihli Vakfiyesinden (Vakfiye I, s.1-2) 


\section{(Sarı Ahmed Paşa'nın Receb 893 Tarihli Vakfiyesi, Vakfiye II)}

الحمدُ لله آلذى نوّر قلوب العارفين بضياء محبّته و تحير عُقول عاثقن فى بيدآء كربايرى عزته و غرقت نفوس ال متاملن فى بحار قدرته و اشرحت صدور الصالحين بحلال اهيبته ثم الصّلوة على رسوله الموّيد بالمغجره الباهره و على اله الموبّد بالنسبته الطاهرة اما بعد فان الدنيا الدنيّه دار غرور و ترح لا دار سرور و فرح نعيمها ظل زايل و مقيمها و ضيفّ راحل الوقف حسنة تدوم فايدتها الى ابد الدّمور و مجرة طييته نظهر ربحها الى يوم الحشر والنشور فلمار ایى برايه الصّايب و نظر بفكره الثاقب ان الاحسان احسن المناقب و الاخرة اولى المارب الذات الخطير الواقف المبير الامير الكبير صاحب الخيرات والحسنات ينبوع القرب والطاعات الواقف المحسن الموبد احمد باثـا بن عبدالصمد ابقى حسناته من خلق السّمآء بغير عمد فوقف وحبس الله تعالى كسابر اوقافه و الحقها مضمومه اليها حسبة الله تعالى ومرضاته وقفا صحيحًا شرعيّا و خير ا صريحا مر عيّا لقد حكم الحاكم الموقع اعلاه على صحَّنه ذلك الو اقف ايضًا كساير ا وقافه المسجلته ثم ان الو اقف المشار اليه لازال مشار اليه وقف و حبس و تعين وسجل من احل ماله و خالص املاكه الرحين المشتر اتين من طورمش احدهما رحى الدقيق و الاحر بيت بدق فها الارز بقال لها بالتركيته دِنك المشتهر تان باسم بايعها بقال لها طورمش دكرمنى فى اعمال مغنيسا المستغنيته عن تحديدها لشهرتها في موضعهما والرحين المشتر اتين عن ولا خو اجه يعقوب فى باطن نفس بيرغمه المستغنيتان عن التحديد لشهرتها فى موضعهما وبيت يدق فها الارز بالمآه فى ناحية بلاموط عن بر انقى المستغنى عن التحديد مثل سابقهاو بيت بدق فيها الارز ايضـا فى قرب قرية كورله المشترى عن تمرتاش بك و بخشايش المستغنيه عن التحديد فى موضعها جميع مع يذكر مع الار اضى الكاينة الصالحته للبنآه و الزر اعته مع حدودها المرقومته فى الحكم الشرعى بجملته حدودها وحقوقها و تو ابعها و لواحقها و مر افقها و بكل حق داخل فيها و خارج عنها وققا صحيحًا شر عيّا و حبسا صريحا مرعيًا الى ساير اوقافه المسجلات المخلدات الى ان يرث الله الارض لمن يثاء و بنى و انشا مدرسثه منيفته و مندبته لطفته لدرس فها على العلوم من التفسير و الحديث و الفقه عند عمارته المبنيته فى بلدة اقحصار المحميته ليعلم فيها الناس الطلبين و يكمل بها عباداله الصالحين عين لجهته التدريس فى كل يوم اثنى عشر در همًا و شرطان يكون المدرس فيها عالما صالحه متوّر عا لايقا للتدريس و للطله الساكنين فيها فى كل يوم خمسته در اهم و ير للامامته و الخطابته والثّاذين فى مسجدة الجامع المبنى في باطن قصبه 
مرمرة المحروسه فى كل سنة سبعماية درهما ثلث ماية درهم منها للموذن ليوذن فيها الاوقاف

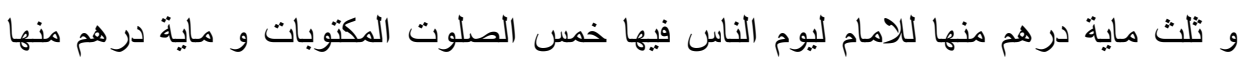

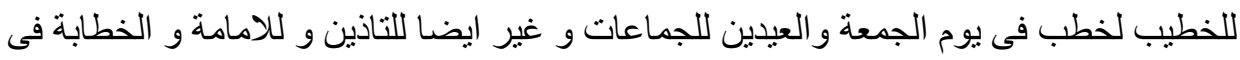
مسجدة الجامع الموّس في كمر المصوته عن المضر في كل سنة سبعماية درهما ثلثماية منها

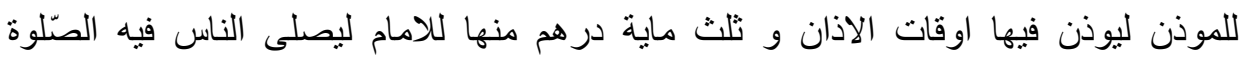
المفروضته لرضاء الرحمان ماية درهم منها للخطيب ليخطب فى يوم الجمعه و العيدان راجيا

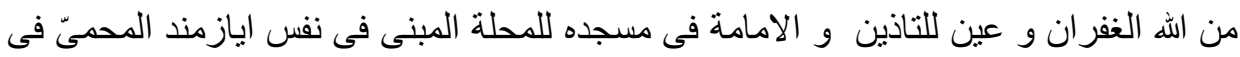

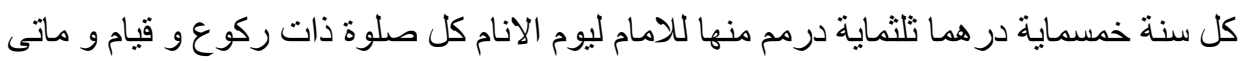

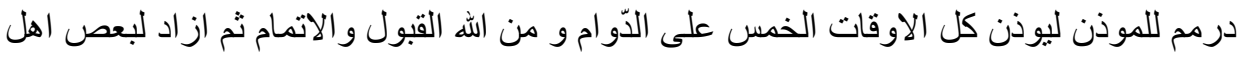
الوضايف قدر اعلى ضيفتهم بقدر معلوم اما للتوليت او لا فى كل يوم ثمانية در اهم ثم ز زاد عليها

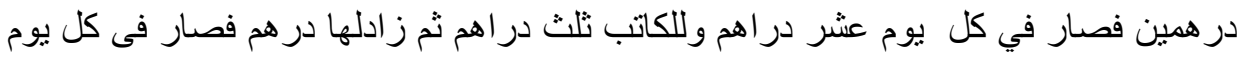

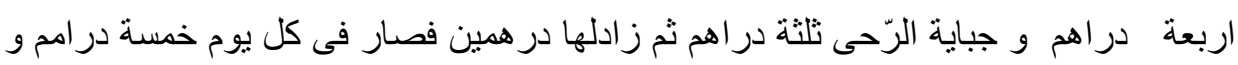

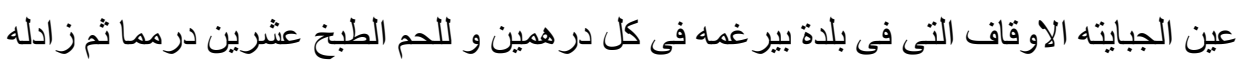

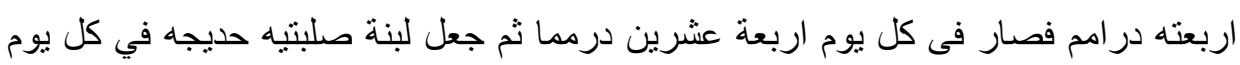

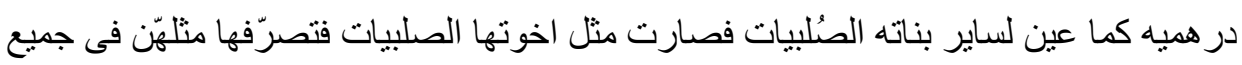

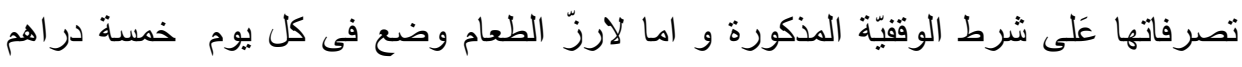

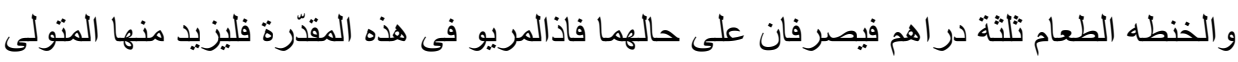

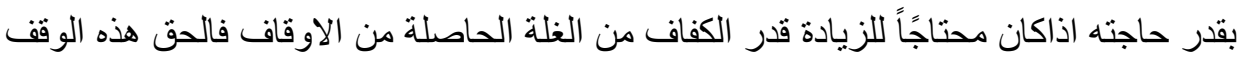
و الثروط الى اصل الوقفيه الحاقا صحيحًا و انضماما صريحا باذن الواقف المسفور ابقى الله خير اته الى يوم الموفور تحرير فى اواخر رجب المرجب سنه ثلثه و تسعين و ثمانماية 